This PDF is a selection from an out-of-print volume from the National Bureau of Economic Research

Volume Title: The Regionalization of the World Economy

Volume Author/Editor: Jeffrey A. Frankel, editor

Volume Publisher: University of Chicago Press

Volume ISBN: 0-226-25995-1

Volume URL: http://www.nber.org/books/fran98-1

Publication Date: January 1998

Chapter Title: The Role of History in Bilateral Trade Flows

Chapter Author: Barry Eichengreen, Douglas A. Irwin

Chapter URL: http://www.nber.org/chapters/c7819

Chapter pages in book: (p. $33-62)$ 


\title{
2 \\ The Role of History in Bilateral Trade Flows
}

\author{
Barry Eichengreen and Douglas A. Irwin
}

\subsection{Introduction}

The rise of regionalism continues to pose challenges for specialists in international trade. One classic question is the aggregate welfare effects of regional trade liberalization. Another is the political economy of regionalism: how liberalization on a regional basis affects the welfare of nations and domestic interest groups, and how their self-interested actions shape the global trading system. A third question, with which we are concerned in this paper, is how important regional arrangements actually have been for the pattern of trade.

The gravity model of international trade has been the workhorse for empirical studies of this question to the virtual exclusion of other approaches. ${ }^{1}$ Trade between two countries is posited to increase with their size (as proxied by their GDPs and populations) and to decline with transactions costs (proxied by the geographic distance between them and by whether or not they share a common border). While there is no close correspondence between the leading theoretical models of trade and the variables appearing in the gravity equation, a number of authors have suggested that the gravity-model framework is compatible both with the Heckscher-Ohlin model and with theories of trade in the presence of imperfect competition. ${ }^{2}$ The attraction of the gravity model (no pun intended) is not simply lack of theoretical incompatibility, of course, but its

Barry Eichengreen is the John L. Simpson Professor of Economics and Political Science at the University of California, Berkeley. Douglas A. Irwin is professor of economics at Dartmouth College.

The authors thank Tam Bayoumi for providing the International Monetary Fund data and Nina Steinberg for assistance in organizing it. Jeffrey Frankel, Robert Lawrence, Tom Rothenberg, Paul Wonnacott, and participants at the Woodstock conference provided helpful comments. This paper was written while Irwin was visiting the American Enterprise lnstitute, whose hospitality is gratefully acknowledged.

1. Frankel (1995) is the most extensive compendium of research adopting this framework.

2. See Anderson (1979); Bergstrand (1985); and Deardorff (1984, chap. 1 of this volume). 
ability to explain the variation in bilateral trade flows across a wide variety of countries and periods. Few aggregate economic relationships are as robust.

To analyze the effects of regionalism, investigators typically add dummy variables for participation in regional arrangements (Hamilton and Winters 1992; Frankel and Wei 1993). A positive coefficient on the dummy variable indicating that two countries, both of which participate in the same preferential arrangement, trade more with one another than predicted by their incomes, population, and distance is interpreted as suggesting that the arrangement is trade-creating for its members. A negative coefficient on a second dummy variable indicating when only one member of the pair participates in a particular preferential arrangement is taken as evidence of trade diversion vis-à-vis the rest of the world.

Empirically, dummy variables for regional arrangements sometimes show up as having substantial trade-creating effects. Two countries both of which are members of one of these regional groupings trade more with one another than would be predicted by their observable economic characteristics (GDP, population, distance from one another) and the average behavior of countries in the sample. Alarmingly, however, they often trade significantly more with one another than otherwise predicted even before the regional arrangement in question came into effect. ${ }^{3}$ One can argue that this reflects the impact on trade of the anticipated implementation of a regional liberalization agreement: suppliers begin to reorient their exports in anticipation of future market opening. In addition, regional arrangements are often preceded by other arrangements that are less formal and less comprehensive in commodity coverage but that include many of the same countries: the European Economic Community was preceded by the European Coal and Steel Community, and the European Payments Union was preceded by the First Agreement on Multilateral Monetary Compensation and the Agreement for Intra-European Payments and Compensations, for example. But the fact that dummy variables for membership in a regional grouping can indicate substantial effects long before the preferential arrangement in question and even its predecessors came into operation, plus the fact that there is little sign of increases in the magnitude of the bloc variable when negotiations quicken or a successful conclusion is reached, gives grounds for skepticism that it is merely expectational effects at work.

Another interpretation of the persistent significance of bloc variables is that members of a regional trade arrangement differ systematically from other countries in ways that promote unusually high levels of intrabloc trade. Measures of bloc membership are thus contaminated by omitted-variables bias. One response to this problem has been to develop measures of the relevant omitted factors. Frankel and Wei (1993) take a step in this direction, adding common language in an effort to pick up cultural and political factors that may reduce transactions costs and encourage bilateral trade.

3. This appears to be the case, for example, in several of the intcrwar trade and payments arrangements considered in Eichengreen and Irwin (1995). 
Another response, as in Bayoumi and Eichengreen (1995), is to estimate the gravity equation in first-difference form, which causes determinants of bilateral trade flows that are constant over time, including unobservable characteristics of countries affecting their propensity to trade, to drop out of the specification. Of course, this does not correct for omitted-variables bias caused by determinants of trade that vary with time. Nor is this procedure suited for samples in which membership in regional arrangements does not change, since the bloc variables will drop out of the differenced specification. ${ }^{4}$

In this paper we take another step by analyzing the impact of history on trade. The idea that past trade patterns influence current trade flows is intuitively plausible. Countries with a history of trading with one anotherwhether for reasons related to politics, policies, or other factors - generally continue doing so. Producers, having set up market-specific sales, distribution, and service networks that allow them to generate a level of exports greater than would be predicted by the scale and geographical distance of the destination market, should continue to generate a disproportionate level of exports over time. Thus, passing historical events that allow costs to be sunk can be associated with persistent increases in the level of trade. The events in question can be anything from a history of colonialism (in which case military means were used to install the infrastructure needed to support bilateral trade) to a history of migration (one thinks of Japanese migration to Brazil and Peru, which provides Latin America with linguistic and cultural capital that supports extensive trade with Japan) to purely chance events.

The recent theoretical and empirical literature suggests a number of other explanations for hysteresis in trade (the possibility that trade does not return to its previous value after a temporary shock). ${ }^{5}$ The existence of economies of scale and scope in the production of goods and services can cause trade to flow in particular geographical channels for historical reasons; thus, a large share of South African exports has long been destined for Britain because economies of scale implied the existence of only one international gold market, which for historical reasons was located in London. A temporary tariff or exchange rate fluctuation that causes foreign firms to establish branch plants in overseas markets-one thinks of "transplant" production by Japanese automotive firmsmay continue to influence trade in intermediate and final goods long after the disturbance is past. Current consumption may be influenced by the history of trade: manufacturers who use steel as an input may shun foreign supplies because they lack familiarity with its quality; a steel strike that interrupts domestic supplies, as happened in the United States in the 1960s and 1970s, may leave them no alternative to imports. As a result, they acquire familiarity with reliable foreign suppliers and consume a permanently higher share of imported

4. Thus, the specification of Frankel, Stein, and Wei (1993), who hold the composition of their European Community bloc constant over time, is not suited to this approach.

5. Hysteresis, strictly speaking, refers to the case where a passing shock to trade has permanent effects. For our purposes, all that is necessary is that a passing shock has effects with significant persistence. 
steel even after the temporary interruption to domestic supplies has passed. Readers will be quick to think of other examples.

The common implication of these stories is that current trade flows should be a positive function of past trade flows even after controlling for the determinants of bilateral trade included in the gravity model. Insofar as other variables included in the gravity equation are correlated with past trade flows, omitting lagged trade will bias their estimated effects. In particular, there is reason to suspect that preferential trade arrangements are positively correlated with past trade flows. Some countries seek to insulate their important trade relations from shocks to the global trade regime by using preferential trade arrangements as safeguards. ${ }^{6}$ Insofar as the creation of the preferential arrangements was itself a response to the unusual importance historically of intrabloc trade, gravity equations omitting lagged trade may overstate the effects of bloc membership.

This is not to suggest that such effects should be equally powerful in all times and places. The influence of past trade over current trade may vary with circumstances; a war, a depression, trade conflict, or an unusually successful global trade negotiation may disrupt established trade relations in ways that lift the heavy hand of history. Similarly, the correlation between past trade flows and regional arrangements will tend to vary with circumstances; the recent literature points to a number of reasons why countries have been attracted to the regional approach to liberalization in recent years. The importance of the factors on which we focus in this paper is ultimately an empirical question.

In practice, isolating the impact of lagged trade on current trade presents not inconsequential estimation problems. As in Griliches's classic article (1961), it may be difficult to distinguish the effects of lagged dependent variables from those of autocorrelated residuals. Although we estimate the model using crosssection rather than time-series data, a standard time-series result carries over: ordinary-least-squares (OLS) estimates of the effects of lagged trade on current trade flows may be biased in the presence of autocorrelated errors. We employ a variety of econometric techniques to address this problem, all of which fortunately tend to yield similar results.

The rest of the paper is organized as follows. Section 2.2 reviews the theoretical literature on hysteresis in trade, emphasizing contributions with potential relevance for the gravity model, and recounts some historical episodes designed to illustrate the applicability of those models. In section 2.3 we present an empirical analysis of historical factors in bilateral trade. Adding historical factors turns out to have important implications for the effects we ascribe to regional arrangements; we draw these out in the conclusion.

6. One motivation for the development of the British system of Commonwealth preferences, for example, was that the unusually extensive network of intra-Commonwealth trade that had developed over the years, as a result of British migration to the overseas regions of recent European settlement and the special protection afforded British investment in its overseas dependencies, was seen as warranting special protection against the corrosive effects of tariff protection in the 1930s. 


\subsection{Theoretical Literature and Historical Illustrations}

Traditional trade theory provides little guidance on the question of how past trade patterns should affect current trade flows. Typically, current trade is related to current factor endowments and current technologies. There is no reason in these models why earlier factor endowments and technologies, much less earlier trade flows, should influence current trade patterns independent of current factor endowments and current technologies.

In contrast, new theories of trade in the presence of monopolistic competition suggest that initial conditions can influence trade flows in ways that introduce a role for history. These theories were developed to analyze, among other things, the possibility of hysteresis in trade. Baldwin (1988), Dixit (1989), Baldwin and Krugman (1989), and others focused on how a large but temporary real exchange rate shock could have permanent effects on the pattern of trade. These effects hinge on sunk costs of market entry and exit for domestic and foreign firms. Sunk costs are associated with the need to set up distribution and sales networks in the foreign markets prior to initiating export sales. A temporary appreciation of a country's currency can make the entry of foreign firms profitable, leading them to undertake a one-time investment in distribution capacity in the domestic market. Even if the currency depreciates back to its initial level, they have no incentive to exit, the up-front costs of distribution and marketing having been sunk. Thus, a temporary exchange rate shock can alter the structural relationship between imports and the exchange rate, permanently affecting the pattern of trade.

Although in this example exchange rate movements are the temporary shock permanently altering the pattern of trade, any number of factors can have such effects. Any temporary disruption to current trade patterns-due to war, depression, or temporary tariffs, for example-could provide an incentive for exporters to sink the fixed costs of penetrating foreign markets.

There is some empirical evidence consistent with these models. Bean (1988) finds evidence from the United Kingdom's trade in the 1980s which suggests structural change in the United Kingdom's export and import patterns as a result of the appreciation of sterling in the early 1980s. Roberts and Tybout (1995), using firm-level data from Colombia, examine the role of fixed costs in determining whether a firm exports or not. They find that previous export experience has a substantial effect on the probability of exporting, rejecting the view that sunk costs are unimportant.

Historical examples may also be useful for illustrating that these mechanisms can actually operate in practice. The point is not to demonstrate hysteresis in trade-that one-time changes in the direction of trade have permanent effects-since this is not necessary for our argument, only to show that changes in trade flows can have effects with significant persistence.

For simplicity, it may help to start with the case of a particular firm. An example is the impact on the exports of the Singer Sewing Machine Company 
of the temporary preferences extended by Australia to British sewing machines in 1907. While imports from other countries paid 10 percent duties, for a period of only a few months machines of British manufacture were admitted free. In response, Singer transferred its Australian business from its American to its British branch. British sewing-machine exports rose, while their U.S. counterparts fell. Importantly for our purposes, Singer's British branch having established the relevant contacts with Australian retailers, the source of exports to Australia did not shift back following the removal of the tariff not long thereafter. Britain, not the United States, remained the dominant source of Singer's exports to Australia (Saul 1960, 218-19). Thus, a one-time rise in British exports of sewing machines due to a purely transitory shock resulted in a persistent rise in British sales to Australia of the product.

It is not obvious, of course, that the effects of changes in the level of trade have comparable effects in the aggregate. Two sources of variation in the aggregate data capable of shedding light on this question are wars and depressions. Consider the effects of World War I on trade in the 1920s. The war was a severe disruption to the pattern of multilateral settlements inherited from the nineteenth century. Insofar as hostilities were concentrated in Europe, its most powerful impact was on intra-European trade and on the trade of European nations with other parts of the world. Because of the sudden shortage of shipping and the diversion of capacity to domestic military uses, the war disrupted exports from Britain to Asia, Africa, and Latin America. The Allies discouraged Latin American countries from exporting raw materials to Germany and maintained a blacklist of firms in Latin America that they believed to be under the control of German nationals. As a result, Latin American customers accustomed to purchasing manufactures from British and German sources suddenly found themselves starved of merchandise. U.S. manufacturers, in contrast, saw an opportunity in the Latin American market vacated by the British and Germans. They set up marketing, distribution, and after-sales service networks; having sunk the costs of entry during the war, they proved hard to dislodge after $1918 .{ }^{7}$ As table 2.1 illustrates, the United Kingdom's share of the imports of every Latin American country fell between 1913 and 1928, while the share of the United States rose for every country but the Guianas. This change occurred despite the absence of significant changes in the relative tariff treatment of Latin American imports from the two sources.

World War I disruptions similarly provided Japan the opportunity to penetrate Asian markets long dominated by European producers. Japan constructed paper mills and factories for the manufacture of drugs, paints, and other products for sale in India and in other Asian markets temporarily vacated by the British. Its textile industry penetrated the Australian market for the first time. The cost of factory construction and distribution having been sunk, the Japa-

7. Moreover, wartime shipbuilding increased the export capacity of the United States and permitted U.S. goods to be transported more cheaply in the 1920s. Additional details beyond those presented here can be found in Kaufman (1974). 
Table 2.1

South American Imports from the United States and United

Kingdom, 1913 and 1928 (percentage share)

\begin{tabular}{lrrrrrrr}
\hline & \multicolumn{3}{c}{ 1913 Imports } & & \multicolumn{3}{c}{ 1928 Imports } \\
\cline { 2 - 3 } \cline { 6 - 7 } Imports of & U.S. & U.K. & Others & & U.S. & U.K. & Others \\
\hline Bolivia & 7.3 & 20.0 & 72.7 & & 29.7 & 17.2 & 53.1 \\
Chile & 16.9 & 30.4 & 52.8 & & 30.8 & 17.8 & 52.8 \\
Ecuador & 32.2 & 30.0 & 37.8 & & 45.7 & 16.0 & 38.3 \\
Peru & 30.0 & 26.7 & 43.3 & & 40.9 & 15.9 & 43.2 \\
Venezuela & 41.2 & 27.1 & 31.7 & 62.2 & 12.2 & 25.6 \\
Brazil & 15.7 & 24.5 & 59.8 & & 26.6 & 21.5 & 51.9 \\
Colombia & 26.7 & 20.4 & 52.9 & & 40.6 & 11.7 & 47.7 \\
Argentina & 14.7 & 31.0 & 54.3 & & 23.2 & 19.6 & 57.2 \\
Paraguay & 6.0 & - & 94 & 16.0 & - & 84 \\
Uruguay & 12.7 & 23.8 & 63.5 & - & - & - \\
Guianas & 23.4 & 56.3 & 20.3 & 12.1 & 55.0 & 32.9 \\
\hline
\end{tabular}

Source: Mitchell 1993, 418-93.

nese did not withdraw from these new markets when British exports came on stream again in the 1920s. In the aggregate, then, the wartime change in the volume of exports from Britain and the United States to Latin America and from Britain and Japan to southern Asia had persistent effects throughout the 1920s.

A further example is the impact of the breakdown of the pattern of multilateral settlements in the 1930s on the post-World War II direction of trade. ${ }^{8}$ The destruction of multilateral trade in the 1930s is too well known to be rehearsed here. Tariffs and nontariff barriers were applied to restrict trade to a series of relatively self-contained trade blocs. Germany in particular used bilateral clearing arrangements and exchange controls to limit its trade to Central and Eastern European countries in its sphere of influence. But the phenomenon was general: as tariffs were raised, countries extended preferences to their overseas territories and to countries associated with them in a monetary area. Thus the share of the exports of Western Europe (including Britain) that flowed to the overseas sterling area rose from 26.8 percent in 1928 to 28.5 percent in 1938 , whereas the share of Western European imports drawn from this area rose from 22.1 to 25.0 percent. Meanwhile, the share of Western European imports drawn from the overseas territories of the continental European countries rose from 4.9 to 8.7 percent (Dewhurst et al. 1961, 655). Increasingly, direct foreign investment flowed through these same channels, with new British factories set up in the sterling area importing capital equipment and suitable raw materials from British sources, and new factories set up by continental European countries in their overseas dependencies doing likewise (Dewhurst et al. 1961, 658).

8. Eichengreen and Irwin (1995) provides references to the literature in which this phenomenon is discussed. 
Thus, the share of Britain's and continental Europe's trade conducted with the sterling area and the overseas territories, respectively, remained high in the wake of World War II. This would appear to be another instance where changes in the pattern of trade in the 1930s, by leading producers to sink fixed costs, had effects on the pattern of trade that were still evident decades later.

It is important to note that this last example admits to an alternative interpretation. Intra-sterling area trade and trade between continental Europe and its colonies could have remained high not because of the impact of sunk costs on trade but because the changes in commercial policy that brought about this shift in the 1930s were not fully reversed in the 1950s. While European countries rolled back their tariffs in early General Agreement on Tariffs and Trade (GATT) rounds (Geneva in 1947, Annecy in 1949, Torquay in 1950-51), many countries in Latin America and Asia were not yet GATT members and did not participate. Thus relatively high tariffs held over from the 1930s could have been responsible for the diversion of trade into imperial channels. Moreover, Britain, when imposing its general tariff in 1932, at the same time extended preferential treatment to its empire; because tariffs were rolled back incompletely in the 1950s, imperial preferences remained. It could have been the persistence of these changes in commercial policy, rather than persistence in trade itself, in other words, that explains this link from the 1930s to the 1950s.

Ultimately, the relative importance of lagged trade and current commercial policy in explaining the pattern of trade is an empirical question, to which we now turn.

\subsection{Empirical Analysis}

\subsubsection{Data and Estimation}

The typical gravity-model specification relates bilateral trade to income, population (or per capita income, as here), contiguity, and distance between the trading partners. Thus the value of bilateral trade between countries $i$ and $j$ in a given year is considered to be a (natural) log-linear function of the independent variables as in the following expression:

$$
\beta_{0}+\beta_{1} \ln \left(Y_{i} Y_{j}\right)+\beta_{2} \ln \left(P_{j} P_{j}\right)+\beta_{3} \ln \left(D I S T_{i j}\right)+\beta_{4}\left(C O N T_{i j}\right)+\varepsilon_{i j},
$$

where $Y_{i} Y_{j}$ is the product of the two countries' national incomes (the so-called gravity variable), $P_{i} P_{j}$ is the product of the two countries' per capita incomes, $D I S T$ is the straight-line distance (in kilometers) between the economic centers of gravity of the two countries, CONT is a dummy variable indicating whether the two countries are contiguous (taking a value of 1 if they share a common border), and $\varepsilon$ is a randomly distributed error term. As trade is expected to increase with size, per capita income, and contiguity, and to decline with distance, $\beta_{1}, \beta_{2}$, and $\beta_{4}$ should be positive, while $\beta_{3}$ should be negative.

Most applications specify the gravity model in double-log form, expressing 
the dependent variable as $\log \left(T R A D E_{i j}\right)$, where $T R A D E_{i j}$ is the value of bilateral trade (exports plus imports) converted into millions of U.S. dollars, and estimate the equation by OLS. The double-log specification permits coefficients to be interpreted as elasticities but omits country pairs for which trade is zero. This is undesirable insofar as the omitted observations contain information about why low levels of trade are observed. One solution is to express the dependent variable in levels and estimate the equation using Tobit, but the results are difficult to interpret because the constant elasticity relationship is lost.

Another approach preserves the double-log form but yields results similar to Tobit. The dependent variable is expressed as $\log (1+T R A D E)$. For large values of $T R A D E, \ln (1+T R A D E) \cong \ln (T R A D E)$, preserving the double-log relationship, while for small values $\ln (1+T R A D E) \cong T R A D E$, approximating the semilog Tobit relationship. The equation can be estimated by scaled OLS, in which the least-squares estimates are multiplied by the reciprocal of the proportion of the observations in which TRADE does not equal zero (Greene 1993, 697). ${ }^{9}$

In the empirical work that follows, we fit the gravity model to our data using each of these specifications and estimators. In addition, we estimate the double-log specification in first differences in order to control for unobservable determinants of trade that are constant over time. Reassuringly, the alternative estimators and specifications yield quite similar results. We therefore focus for simplicity on the scaled-OLS estimates.

We estimate the model using data on interwar and postwar trade flows. Interwar trade data from 1928 and 1938 are available from Hilgert (1942). Data for national income in these years, drawn from sources described in the appendix to Eichengreen and Irwin (1995), are converted to millions of U.S. dollars using the exchange rates provided by Hilgert. ${ }^{10}$ The limited availability of national income data reduces the interwar data set to thirty-four countries, yielding 561 bilateral trade observations. Our postwar trade data are drawn from the International Monetary Fund's Direction of Trade Statistics, while national income and population data are from the IMF's International Financial Statistics. We gathered data for the immediate postwar period in order to concentrate on the effects of interwar trade patterns for the postwar development of trade. We selected data from 1949, 1954, and 1964; 1949 is just after the first GATT negotiating round and a time when postwar trade routes were still being reestablished, while 1954 and 1964 are, respectively, prior to and after the forma-

9. If any of the independent variables are correlated with the disturbance term, OLS will produce biased estimates. In particular, there is reason to worry that if trade is measured with error, national income will be measured with error as well, since trade is a component of income. In Eichengreen and Irwin (1995) we estimated the basic specification by both OLS and instrumental variables. For the interwar years considered there, the use of instruments made little difference for the results. Below we report some instrumental variables estimates implemented in a different fashion.

10. This appendix also describes the sources from which interwar population figures were drawn. 
Table 2.2

Basic Determinants of Bilateral Trade, 1928 and 1938

\begin{tabular}{|c|c|c|c|c|c|c|}
\hline \multirow[b]{2}{*}{ Estimation Method } & \multicolumn{3}{|c|}{1928} & \multicolumn{3}{|c|}{1938} \\
\hline & OLS Logs & OLS Scaled & Tobit & OLS Logs & OLS Scaled & Tobit \\
\hline Mean dependent variable & 2.49 & 2.01 & 42.34 & 2.22 & 1.85 & 27.27 \\
\hline Constant & $\begin{array}{c}-4.93 \\
(6.85)\end{array}$ & $\begin{array}{l}4.19 \\
(5.76)\end{array}$ & $\begin{array}{c}-8.71 \\
(7.93)\end{array}$ & $\begin{array}{l}-6.24 \\
(8.53)\end{array}$ & $\begin{array}{c}4.86 \\
(6.66)\end{array}$ & $\begin{array}{r}-10.79 \\
(9.91)\end{array}$ \\
\hline National incomes & $\begin{array}{c}0.90 \\
(20.50)\end{array}$ & $\begin{array}{c}0.91 \\
(27.58)\end{array}$ & $\begin{array}{c}1.14 \\
(17.62)\end{array}$ & $\begin{array}{c}0.86 \\
(19.73)\end{array}$ & $\begin{array}{c}0.77 \\
(23.65)\end{array}$ & $\begin{array}{r}1.11 \\
(17.42)\end{array}$ \\
\hline $\begin{array}{l}\text { Per capita national } \\
\text { incomes }\end{array}$ & $\begin{array}{c}0.89 \\
(16.30)\end{array}$ & $\begin{array}{c}0.33 \\
(6.28)\end{array}$ & $\begin{array}{c}1.30 \\
(15.96)\end{array}$ & $\begin{array}{c}0.73 \\
(16.59)\end{array}$ & $\begin{array}{c}0.16 \\
(3.62)\end{array}$ & $\begin{array}{r}1.04 \\
(16.64)\end{array}$ \\
\hline Distance & $\begin{array}{c}-0.51 \\
(8.67)\end{array}$ & $\begin{array}{l}-0.78 \\
(12.63)\end{array}$ & $\begin{array}{c}-0.56 \\
(6.34)\end{array}$ & $\begin{array}{c}-0.37 \\
(6.79)\end{array}$ & $\begin{array}{c}-0.53 \\
(8.64)\end{array}$ & $\begin{array}{r}-0.33 \\
(4.08)\end{array}$ \\
\hline Contiguity & $\begin{array}{c}0.47 \\
(2.02)\end{array}$ & $\begin{array}{c}0.79 \\
(2.94)\end{array}$ & $\begin{array}{l}1.38 \\
(3.75)\end{array}$ & $\begin{array}{c}0.30 \\
(1.37)\end{array}$ & $\begin{array}{c}0.45 \\
(1.69)\end{array}$ & $\begin{array}{r}1.19 \\
(3.55)\end{array}$ \\
\hline$R^{2}$ & 0.59 & 0.69 & 0.33 & 0.58 & 0.62 & 0.31 \\
\hline Standard error & 3.08 & 3.20 & 1.91 & 2.58 & 2.61 & 1.64 \\
\hline$N$ & 419 & 561 & 561 & 426 & 561 & 561 \\
\hline
\end{tabular}

Source: Eichengreen and Irwin 1995, 11.

Note: $T$-statistics are in parentheses.

tion of the European Economic Community; these dates are well suited, therefore, for analyzing the effects of regional and global liberalization initiatives. The postwar sample consists of thirty-eight countries, yielding 703 bilateral observations in each year. In addressing whether interwar trade patterns still affect postwar trade patterns, we augment the prewar trade data with additional observations on bilateral trade from Hilgert to match the larger postwar sample.

\subsubsection{Results}

To analyze the impact of historical factors, we proceed in steps, starting with the standard gravity-model specification, adding lagged trade, and then turning to the effects of blocs.

\section{Basic Specification}

Table 2.2 summarizes the findings from our earlier paper regarding interwar trade patterns. This provides a basis for comparison with the present paper's results for the postwar period. All of the arguments of the standard gravity model reported in table 2.2 enter with their expected signs and differ significantly from zero at standard confidence levels. In addition, the alternative estimators deliver very similar results."

Table 2.3 provides analogous estimates for 1949,1954 , and 1964. Again, the

11. The coefficient on per capita incomes is somewhat smaller when the model is estimated scaled OLS than when plain-vanilla OLS is used. 
alternative estimators and specifications deliver broadly similar results. ${ }^{12}$ In contrast to table 2.2 , for the early postwar period the coefficient on per capita incomes is not sensitive to the substitution of $\log (1+T R A D E)$ for $\log$ $(T R A D E)$ and the use of scaled OLS rather than regular OLS.

In conjunction with table 2.2 , table 2.3 allows us to trace the evolution of the coefficients over time. The coefficient on the product of national incomes, for example, declines slightly between the 1920s and 1930s but recovers to 1920s levels after World War II. An interpretation is that trade restrictions imposed in the 1930s reduced the elasticity of trade with respect to national income but that this trend was reversed after the war.

The same basic pattern is evident for per capita incomes, except that the coefficient on this variable is small and statistically indistinguishable from zero in 1949. This coefficient is typically interpreted in terms of intraindustry trade: richer economies consume a wider variety of differentiated products than poorer countries, and many of those differentiated varieties are produced abroad; hence, richer countries should engage in more intraindustry trade than their poorer counterparts. The insignificance of this coefficient in 1949 is consistent with the notion that intraindustry trade was depressed in the aftermath of World War II by the slow progress of reconstruction in Europe, which prevented the countries of that continent from exporting the traditional level of manufactures to the United States, and by the dollar gap, which prevented Europe from importing much from the United States other than essential raw materials and capital goods. (For details see Eichengreen 1993.)

The scaled-OLS estimates indicate that the effect of per capita incomes had been restored by 1954, suggesting that the prewar pattern of intraindustry trade had been successfully reestablished by the midfifties. But estimating the model in first differences continues to yield an insignificant coefficient on this variable in 1954, suggesting that this restoration was delayed until somewhat later. $^{13}$

The coefficient on distance is greater in size and significance in 1949 than in other years, perhaps reflecting the difficulty of reestablishing and reconstructing transportation networks, especially over long distances, in the aftermath of World War II. More generally, however, it exhibits little trend. This is not to say that there was no decline in transportation costs over time. If there is "distance-neutral" technological progress in the provision of transportation services, then the cost of transporting goods over various distances will decline proportionately, and we will observe no change in the magnitude of the distance coefficient. Only if technical progress is "distance saving," in the sense that it reduces the cost of transporting goods over long distances more than the cost of transporting them over short ones, would we expect to see the magni-

12. An exception is the first-difference specification, whose use alters the coefficients on per capita incomes in 1954 and national incomes in 1964. We return to this point below.

13. We find the same thing when we use Hatanaka's method to estimate a variant of the gravity model including lagged trade in quasi-differenced form, as described below. 
Basic Determinants of Bilateral Trade, 1949, 1954, and 1964

\begin{tabular}{|c|c|c|c|c|c|c|c|c|c|c|c|c|c|c|}
\hline & \multicolumn{4}{|c|}{1949} & \multicolumn{5}{|c|}{1954} & \multicolumn{5}{|c|}{1964} \\
\hline & $\begin{array}{c}\text { OLS } \\
\text { Levels }\end{array}$ & $\begin{array}{l}\text { OLS } \\
\text { Logs }\end{array}$ & $\begin{array}{c}\text { OLS } \\
\text { Scaled }\end{array}$ & Tobit & $\begin{array}{c}\text { OLS } \\
\text { Levels }\end{array}$ & $\begin{array}{l}\text { OLS } \\
\text { Logs }\end{array}$ & $\begin{array}{l}\text { OLS } \\
\text { Scaled }\end{array}$ & Tobit & $\begin{array}{c}\text { First } \\
\text { Difference }\end{array}$ & OLS Levels & $\begin{array}{l}\text { OLS } \\
\text { Logs }\end{array}$ & $\begin{array}{c}\text { OLS } \\
\text { Scaled }\end{array}$ & Tobit & $\begin{array}{c}\text { First } \\
\text { Difference }\end{array}$ \\
\hline $\begin{array}{l}\text { Mean } \\
\text { dependent } \\
\text { variable }\end{array}$ & 48.86 & 2.18 & 1.95 & 39.72 & 80.29 & 2.47 & 2.35 & 78.72 & 0.40 & 152.63 & 3.05 & 2.86 & 149.3 & 0.51 \\
\hline Constant & $\begin{array}{l}34.84 \\
(3.02)\end{array}$ & $\begin{array}{c}5.52 \\
(9.05)\end{array}$ & $\begin{array}{c}6.86 \\
(11.44)\end{array}$ & $\begin{array}{c}8.48 \\
(7.22)\end{array}$ & $\begin{array}{r}101.10 \\
(4.56)\end{array}$ & $\begin{array}{c}5.23 \\
(9.17)\end{array}$ & $\begin{array}{c}6.19 \\
(11.93)\end{array}$ & $\begin{array}{c}9.29 \\
(8.12)\end{array}$ & $\begin{array}{c}0.34 \\
(7.76)\end{array}$ & $\begin{array}{r}137.15 \\
(4.80)\end{array}$ & $\begin{array}{c}4.94 \\
(9.22)\end{array}$ & $\begin{array}{c}5.63 \\
(11.13)\end{array}$ & $\begin{array}{c}9.12 \\
(8.29)\end{array}$ & $\begin{array}{c}-0.17 \\
(1.48)\end{array}$ \\
\hline $\begin{array}{l}\text { National } \\
\text { incomes }\end{array}$ & $\begin{array}{c}0.14 \\
(17.57)\end{array}$ & $\begin{array}{c}0.89 \\
(23.76)\end{array}$ & $\begin{array}{c}1.00 \\
(28.66)\end{array}$ & $\begin{array}{c}1.09 \\
(19.39)\end{array}$ & $\begin{array}{r}-0.03 \\
(0.48)\end{array}$ & $\begin{array}{c}0.87 \\
(24.80)\end{array}$ & $\begin{array}{c}0.91 \\
(29.91)\end{array}$ & $\begin{array}{c}1.15 \\
(20.34)\end{array}$ & $\begin{array}{c}0.31 \\
(3.19)\end{array}$ & $\begin{array}{c}0.06 \\
(22.41)\end{array}$ & $\begin{array}{c}0.87 \\
(27.44)\end{array}$ & $\begin{array}{c}0.92 \\
(31.90)\end{array}$ & $\begin{array}{c}1.19 \\
(21.87)\end{array}$ & $\begin{array}{c}0.14 \\
(0.69)\end{array}$ \\
\hline $\begin{array}{l}\text { Per capita } \\
\text { national } \\
\text { incomes }\end{array}$ & $\begin{array}{c}-0.00 \\
(1.98)\end{array}$ & $\begin{array}{c}0.05 \\
(0.72)\end{array}$ & $\begin{array}{c}0.05 \\
(0.88)\end{array}$ & $\begin{array}{c}0.13 \\
(1.20)\end{array}$ & $\begin{array}{c}0.01 \\
(0.36)\end{array}$ & $\begin{array}{c}0.29 \\
(6.46)\end{array}$ & $\begin{array}{c}0.33 \\
(8.29)\end{array}$ & $\begin{array}{c}0.93 \\
(7.29)\end{array}$ & $\begin{array}{r}-0.02 \\
(0.69)\end{array}$ & $\begin{array}{c}-0.01 \\
(2.48)\end{array}$ & $\begin{array}{c}0.36 \\
(9.34)\end{array}$ & $\begin{array}{c}0.38 \\
(11.17)\end{array}$ & $\begin{array}{c}1.01 \\
(8.92)\end{array}$ & $\begin{array}{c}0.52 \\
(3.01)\end{array}$ \\
\hline Distance & $\begin{array}{c}-0.00 \\
(1.56)\end{array}$ & $\begin{array}{l}-0.82 \\
(11.38)\end{array}$ & $\begin{array}{l}-0.95 \\
(13.64)\end{array}$ & $\begin{array}{c}-0.63 \\
(4.31)\end{array}$ & $\begin{array}{c}-0.01 \\
(1.98)\end{array}$ & $\begin{array}{c}-0.70 \\
(10.22)\end{array}$ & $\begin{array}{l}-0.76 \\
(12.32)\end{array}$ & $\begin{array}{c}-0.45 \\
(3.59)\end{array}$ & - & $\begin{array}{c}-0.01 \\
(3.30)\end{array}$ & $\begin{array}{l}-0.76 \\
(12.05)\end{array}$ & $\begin{array}{l}-0.81 \\
(13.67)\end{array}$ & $\begin{array}{c}-0.40 \\
(2.99)\end{array}$ & - \\
\hline Contiguity & $\begin{array}{c}242.01 \\
(7.85)\end{array}$ & $\begin{array}{c}0.21 \\
(0.62)\end{array}$ & $\begin{array}{c}0.37 \\
(1.11)\end{array}$ & $\begin{array}{c}0.92 \\
(1.92)\end{array}$ & $\begin{array}{r}464.52 \\
(8.05)\end{array}$ & $\begin{array}{c}0.34 \\
(1.06)\end{array}$ & $\begin{array}{c}0.41 \\
(1.40)\end{array}$ & $\begin{array}{c}0.98 \\
(2.14)\end{array}$ & - & $\begin{array}{c}1037.8 \\
(13.58)\end{array}$ & $\begin{array}{c}0.19 \\
(0.65)\end{array}$ & $\begin{array}{c}0.25 \\
(0.91)\end{array}$ & $\begin{array}{c}1.01 \\
(1.89)\end{array}$ & - \\
\hline$R^{2}$ & 0.39 & 0.59 & 0.63 & 0.28 & 0.12 & 0.64 & 0.71 & 0.30 & 0.02 & 0.54 & 0.73 & 0.77 & 0.31 & 0.19 \\
\hline $\begin{array}{c}\text { Standard } \\
\text { error }\end{array}$ & 142.1 & 1.35 & 1.11 & 1.25 & 259.87 & 1.31 & 1.05 & 1.40 & 0.78 & 351.73 & 1.20 & 1.02 & 1.39 & 0.65 \\
\hline$N$ & 703 & 545 & 703 & 703 & 703 & 595 & 703 & 703 & 703 & 703 & 611 & 703 & 703 & 703 \\
\hline
\end{tabular}

Notes: $R^{2}$ in the Tobit regression is the squared correlation between the actual and fitted value of the dependent variable. $T$-statistics are in parentheses. 
Table 2.4 Basic Determinants of Bilateral Trade, Including Lagged Trade

\begin{tabular}{lccc}
\hline & 1949 & 1954 & 1964 \\
\hline Constant & 4.06 & 1.36 & 2.52 \\
& $(7.26)$ & $(3.66)$ & $(7.80)$ \\
National incomes & 0.50 & 0.25 & 0.27 \\
& $(10.77)$ & $(6.64)$ & $(9.77)$ \\
Per capita national incomes & 0.06 & 0.15 & 0.20 \\
& $(1.19)$ & $(5.81)$ & $(9.02)$ \\
Distance & -0.54 & -0.13 & -0.30 \\
& $(8.11)$ & $(2.80)$ & $(7.64)$ \\
Contiguity & -0.03 & -0.03 & -0.01 \\
& $(0.09)$ & $(0.17)$ & $(0.06)$ \\
Trade in 1954 & - & - & 0.94 \\
& & & $(23.69)$ \\
Trade in 1949 & - & 0.70 & -0.02 \\
& & $(22.38)$ & $(0.59)$ \\
Trade in 1938 & 0.34 & 0.22 & -0.09 \\
& $(6.60)$ & $(5.08)$ & $(2.43)$ \\
Trade in 1928 & 0.15 & 0.03 & 0.09 \\
& $(2.09)$ & $(0.75)$ & $(0.64)$ \\
Implied long-run income & 1.0 & 2.6 & 4.5 \\
elasticity & & & \\
$R^{2}$ & 0.72 & 0.88 & 0.92 \\
Standard error & 0.97 & 0.68 & 0.62 \\
$F$-statistic & 299.44 & 717.29 & 974.50 \\
\hline
\end{tabular}

Notes: Estimated by scaled OLS, where the dependent variable is $\ln (1+T R A D E)$. T-statistics are in parentheses.

tude of this coefficient decline; there is no evidence of this across our sample years.

\section{Adding Lagged Trade}

Table 2.4 shows the effect of adding lagged trade to this basic specification. The first column presents the results for trade in 1949, with lagged dependent variables for 1928 and $1938 .{ }^{14}$ Current incomes and distance still help to predict current trade, but the magnitude of their coefficients is reduced. Trade in both 1938 and 1928 exerts independent and statistically significant effects on trade in 1949 and significantly raises the share of the variation in the dependent variable accounted for by the model. These estimates suggest that an extra dollar of trade in 1938 and 1928 raised the predicted value of 1949 trade by 50 cents. The influence of past trade patterns on current trade flows diminishes with time: the coefficient on 1938 trade is greater than that on 1928 trade by a factor of two. One might have anticipated that 1928 trade would have had a

14. We adjust the lagged values of trade by the change in the U.S. wholesale price index between these years and the year of interest in the regression, to have comparable nominal values of trade. This permits the lagged coefficients to be interpreted more easily. 
stronger impact than 1938 on the direction and volume of postwar trade; that component of 1928 trade not strongly correlated with relative incomes and geographic distance plausibly reflected unobservable economic characteristics of countries that encouraged them to trade disproportionately with one another - characteristics that should have continued to influence the direction of trade after World War II. In contrast, 1938 trade was strongly shaped by the transitory trade restrictions of the 1930s and, absent strong hysteresis effects, should not have continued to exert the stronger role after World War II. It is striking, therefore, that the value for 1938 continues to exert the stronger effect in 1949. This is consistent with our interpretation of the lags as capturing hysteresis effects rather than merely as proxies for unobservable structural characteristics.

In this augmented specification, the coefficients on the standard arguments of the gravity model can be interpreted as short-run, or impact, effects. To derive the implicit long-run elasticities, we divide through by one minus the sum of the coefficients on the lagged dependent variables. In the standard regression, the coefficient on national incomes is approximately unity; a doubling of income implies a doubling of trade. The estimates for 1949 in table 2.4 suggest that, while the short-run increase in trade due to a doubling of income is on the order of 50 percent, the estimated long-run elasticity of trade with respect to income is about one, close to the results from the specification that does not include lagged trade.

The column for trade in 1954 tells a similar story that differs in one important particular. The coefficients on national incomes, per capita national incomes, and distance are smaller than in the specification that excludes past trade but remain statistically significant at standard confidence levels. Those on lagged trade (included here for 1949, 1938, and 1928) exhibit the same decaying pattern over time as in the regression for 1949. The coefficients on the first two lags differ significantly from zero at standard confidence levels, but not that for 1928. The sum of the coefficients on lagged trade sum to about 0.9 . By these calculations, the estimated long-run income and per capita income effects are significantly higher in the augmented specification than when the standard gravity model is estimated. While the short-run impact of an increase in incomes on trade is estimated to be 0.25 , the long-run impact is closer to 2.5. These results are consistent with the observation that trade has grown more quickly than income over the postwar period.

In 1964, in contrast, only 1954 trade and not the values for 1949, 1938, and 1928 has its anticipated positive effect. Perhaps after twenty years the postwar recovery and the GATT process had sufficiently changed the orientation of trade that its own footprints dominated those of earlier years. ${ }^{15}$ Like the results obtained for 1954, the coefficient on lagged trade is about 0.94 . This implies that, while the short-run impact of incomes on trade is only 0.27 , the long-run

15. We analyze this hypothesis explicitly in the next subsection. 
impact is 4.5. The large coefficients on lagged trade suggest a high degree of persistence in trading patterns and imply that small changes in current trade patterns can end up having quite large long-run effects. ${ }^{16}$

Here as elsewhere, the interpretation of lagged dependent variables is problematic. On the one hand, a large coefficient on lagged trade could indicate that a greater propensity to trade in the past actually has the economic effect of encouraging greater trade in the present; on the other, the lagged dependent variable could simply be picking up the effects of random factors which cause some country pairs to trade more than others. Some bilateral trade flows may be unusually high, in other words, because of persistent error terms rather than hysteresis in trade per se. And the combination of autocorrelated errors and lagged dependent variables introduces the possibility of biased coefficient estimates due to the correlation between the lagged variable and the error term.

A standard approach to estimation in this case is to instrument lagged trade (Liviatan 1963). Since by assumption the instrumental variables are uncorrelated in the probability limit with the disturbance, substituting the instrumented value of lagged trade will yield consistent estimates (although those estimates will not be efficient since the adjustment has not dealt with the autocorrelation of the disturbance terms). Obvious instruments are the arguments of the gravity model (lagged incomes, lagged incomes per capita). Intuitively, including only the predicted, or systematic, component of lagged trade enhances the plausibility of our interpretation that the lagged value is picking up hysteresis in trade rather than simply persistent random effects.

The second column of table 2.5 reports the results employing fitted values of lagged trade. (For comparison, the first column shows the same regressions estimated by OLS.) Lagged trade continues to have an economically important and statistically significant impact on current trade flows in both 1949 and 1954 , although its magnitude is somewhat reduced, as expected. In the equation for 1949 , the coefficient on lagged trade declines from 0.68 to 0.41 when the fitted value is substituted for the actual one. In the equation for 1954, it declines from 0.83 to 0.60 . In 1964 , it declines from a relatively large 0.89 to essentially zero.

Another approach to this question is Hatanaka's two-step method. This uses instrumental variables to obtain a consistent estimate of the autocorrelation coefficient, adds both the fitted value of lagged trade and the residual from that first-stage regression to the gravity model, and reestimates the equation in quasi-differenced form. Thus this approach deals both with the problem of obtaining consistent estimates and with that of autocorrelated residuals. An

16. This strong persistence implies that lagged trade is an excellent predictor of current trade in the postwar sample. For example, a regression of 1964 trade on a constant and 1954 trade and no other explanatory variables yields a coefficient on lagged trade of 1.04 with a standard error of 0.01 and an $R^{2}$ of 0.89 . Explaining 1954 trade by 1949 trade and a constant yields a coefficient of 0.96 (with a standard error of 0.02 ) and an $R^{2}$ of 0.83 . By contrast, explaining postwar trade from interwar trade typically yields coefficients of less than 0.9 with less explanatory power. 
Table 2.5

Basic Determinants of Bilateral Trade, Including Fitted Values of Lagged Trade

\begin{tabular}{|c|c|c|c|c|c|c|}
\hline \multirow[b]{2}{*}{ Constant } & \multicolumn{3}{|c|}{1954} & \multicolumn{3}{|c|}{1964} \\
\hline & $\begin{array}{c}1.87 \\
(4.87)\end{array}$ & $\begin{array}{c}2.80 \\
(3.11)\end{array}$ & $\begin{array}{c}1.58 \\
(2.55)\end{array}$ & $\begin{array}{c}2.51 \\
(7.79)\end{array}$ & $\begin{array}{c}5.05 \\
(7.33)\end{array}$ & $\begin{array}{r}4.45 \\
(11.07\end{array}$ \\
\hline National incomes & $\begin{array}{c}0.31 \\
(10.72)\end{array}$ & $\begin{array}{c}0.44 \\
(4.14)\end{array}$ & $\begin{array}{c}0.29 \\
(3.92)\end{array}$ & $\begin{array}{c}0.25 \\
(9.70)\end{array}$ & $\begin{array}{c}0.86 \\
(9.73)\end{array}$ & $\begin{array}{r}0.57 \\
(11.07)\end{array}$ \\
\hline $\begin{array}{l}\text { Per capita national } \\
\text { incomes }\end{array}$ & $\begin{array}{c}0.14 \\
(5.15)\end{array}$ & $\begin{array}{c}0.37 \\
(9.29)\end{array}$ & $\begin{array}{c}0.15 \\
(5.05)\end{array}$ & $\begin{array}{c}0.20 \\
(9.55)\end{array}$ & $\begin{array}{c}0.47 \\
(8.80)\end{array}$ & $\begin{array}{r}0.15 \\
(4.79\end{array}$ \\
\hline Distance & $\begin{array}{c}-0.20 \\
(4.41)\end{array}$ & $\begin{array}{c}-0.28 \\
(2.28)\end{array}$ & $\begin{array}{c}-0.17 \\
(2.04)\end{array}$ & $\begin{array}{c}-0.29 \\
(7.49)\end{array}$ & $\begin{array}{l}-0.70 \\
(7.25)\end{array}$ & $\begin{array}{l}-0.62 \\
(10.97)\end{array}$ \\
\hline Contiguity & $\begin{array}{c}0.12 \\
(0.62)\end{array}$ & $\begin{array}{c}0.25 \\
(0.85)\end{array}$ & $\begin{array}{c}0.14 \\
(0.72)\end{array}$ & $\begin{array}{c}0.05 \\
(0.33)\end{array}$ & $\begin{array}{c}0.25 \\
(0.89)\end{array}$ & $\begin{array}{r}0.08 \\
(0.48)\end{array}$ \\
\hline $\begin{array}{l}\text { Actual trade in } \\
1949\end{array}$ & $\begin{array}{c}0.83 \\
(28.48)\end{array}$ & - & - & $\begin{array}{c}0.04 \\
(1.16)\end{array}$ & - & - \\
\hline Fitted trade in 1949 & - & $\begin{array}{c}0.60 \\
(4.56)\end{array}$ & $\begin{array}{c}0.85 \\
(9.32)\end{array}$ & - & $\begin{array}{c}0.31 \\
(2.44)\end{array}$ & $\begin{array}{r}0.34 \\
(4.24\end{array}$ \\
\hline $\begin{array}{l}\text { Residual from fitted } \\
\text { trade, } 1949\end{array}$ & - & - & $\begin{array}{c}0.81 \\
(27.94)\end{array}$ & - & - & $\begin{array}{r}0.01 \\
(0.45)\end{array}$ \\
\hline $\begin{array}{l}\text { Actual trade in } \\
1954\end{array}$ & - & - & - & $\begin{array}{c}0.93 \\
(23.94)\end{array}$ & - & - \\
\hline Fitted trade in 1954 & - & 一 & - & - & $\begin{array}{c}0.23 \\
(1.53)\end{array}$ & $\begin{array}{r}0.78 \\
(8.08)\end{array}$ \\
\hline $\begin{array}{l}\text { Residual from fitted } \\
\text { trade, } 1954\end{array}$ & - & - & - & - & - & $\begin{array}{r}0.93 \\
(25.26)\end{array}$ \\
\hline$R^{2}$ & 0.86 & 0.72 & 0.86 & 0.92 & 0.78 & 0.92 \\
\hline Standard error & 0.71 & 1.03 & 0.71 & 0.62 & 1.01 & 0.59 \\
\hline$F$-statistic & 888.7 & 349.9 & 747.9 & 1279.3 & 401.5 & 1053.7 \\
\hline
\end{tabular}

Note: See table 2.4 notes.

economic argument for including both the fitted values of lagged trade and the residual from the first-stage equation is that changes in lagged trade due to both systematic (observable) and random (unobservable) factors will tend to influence current trade patterns, although the magnitude of their effects may differ.

We show the results in the third and sixth columns of table 2.5 . These estimates again reduce the magnitude of the coefficient on the lagged dependent variable, although it remains statistically significant at standard confidence levels for both cross-section years. ${ }^{17}$ They produce a pattern of coefficients on lagged trade that decline over time, as if the heavy hand of interwar commercial history was gradually lifted over the postwar years. The coefficient on the residual from the first-stage regression is consistently less significant and important than that on the fitted value of trade, as if movements in trade due to systematic factors associated with the gravity model have a more persistent

17. Thus, where estimation by instrumental variables yielded a zero coefficient on the lagged dependent variable in 1964, Hatanaka's method yields a statistically significant coefficient of 0.10 . 
impact on future trade patterns than idiosyncratic fluctuations in trade. Only in 1954 does the coefficient on the first-stage residual differ significantly from zero at the 90 percent confidence level.

The use of Hatanaka's method enhances the importance of continuity in 1954, and it lengthens (through 1954) the postwar period over which our intraindustry-trade proxy (per capita incomes) fails to regain its effect. By reducing the magnitude of the coefficient on the lagged dependent variable, it no longer suggests a long-run elasticity of trade with respect to income greater than unity (or greater than the scaled-OLS estimates). Otherwise, the coefficients on the other variables remain essentially unchanged.

Thus, estimating the extended gravity model using a variety of alternative approaches does not fundamentally alter the results. It does not undermine our interpretation of the lagged dependent variable in terms of the economic effects of lagged trade flows on current trade patterns, operating through channels like those highlighted in recent models of hysteresis in trade. For simplicity and in the interest of comparability with other studies, in the remaining subsections we concentrate on our scaled-OLS results.

\section{Trade and Financial Bloc Variables}

Table 2.6 adds dummy variables designed to capture the impact of the two principal trade liberalization initiatives of the early postwar period, GATT and the European Economic Community (EEC). GATT was initiated in 1947, when twenty-three participating countries agreed to exchange tariff reductions and to extend to one another most-favored-nation (MFN) trading status. ${ }^{18}$ The EEC was formed in 1958 when six European countries agreed to establish a customs union..$^{19}$

Including dummy variables is the standard way of assessing the impact of such trade arrangements in the gravity-model framework. In our regressions, one dummy variable for each arrangement takes a value of 1 when a pair of countries both participate in GATT or the EEC. A positive coefficient on this variable indicates "trade creation," or that the two countries trade more with each other than would be predicted by their incomes, populations, and geographical location and the average behavior of countries in the sample. A second set of dummy variables takes on a value of $I$ if only one of the two countries participates in the trade arrangement in question. This variable captures the "external effect" of the grouping on trade with nonmembers. A positive coefficient indicates greater trade with nonmembers, a negative one "trade diversion," or a reduction in trade with nonmembers.

Previous assessments of trade blocs and regional arrangements utilizing this

18. Twenty-nine of the thirty-four members of GATT in 1949 are in our sample; thirty-four of forty-one members of GATT are in our 1954 sample; and thirty of sixty-nine members of GATT are in our 1964 sample.

19. Each of the founding members of the EEC-Belgium-Luxembourg, France, Germany, Italy, the Netherlands-is in our sample. 
Table 2.6

Determinants of Bilateral Trade, Including Lagged Trade and Commercial Initiatives

\begin{tabular}{|c|c|c|c|c|c|c|}
\hline \multirow[b]{2}{*}{ Constant } & \multicolumn{2}{|c|}{1949} & \multicolumn{2}{|c|}{1954} & \multicolumn{2}{|c|}{1964} \\
\hline & $\begin{array}{c}7.00 \\
(12.10)\end{array}$ & $\begin{array}{c}5.03 \\
(9.27)\end{array}$ & $\begin{array}{c}5.62 \\
(10.43)\end{array}$ & $\begin{array}{c}1.68 \\
(3.83)\end{array}$ & $\begin{array}{c}4.46 \\
(7.48)\end{array}$ & $\begin{array}{r}1.89 \\
(5.84)\end{array}$ \\
\hline National incomes & $\begin{array}{c}0.85 \\
(23.59)\end{array}$ & $\begin{array}{r}0.48 \\
(10.91)\end{array}$ & $\begin{array}{c}0.85 \\
(26.78)\end{array}$ & $\begin{array}{c}0.30 \\
(10.09)\end{array}$ & $\begin{array}{c}0.87 \\
(28.92)\end{array}$ & $\begin{array}{c}0.21 \\
(9.36)\end{array}$ \\
\hline $\begin{array}{l}\text { Per capita } \\
\text { national incomes }\end{array}$ & $\begin{array}{c}0.00 \\
(0.02)\end{array}$ & $\begin{array}{c}0.00 \\
(0.03)\end{array}$ & $\begin{array}{c}0.30 \\
(7.59)\end{array}$ & $\begin{array}{c}0.14 \\
(5.27)\end{array}$ & $\begin{array}{c}0.37 \\
(10.77)\end{array}$ & $\begin{array}{r}0.18 \\
(9.66)\end{array}$ \\
\hline Distance & $\begin{array}{l}-0.98 \\
(14.40)\end{array}$ & $\begin{array}{l}-0.67 \\
(10.34)\end{array}$ & $\begin{array}{l}-0.70 \\
(11.05)\end{array}$ & $\begin{array}{l}-0.14 \\
(3.02)\end{array}$ & $\begin{array}{l}-0.74 \\
(12.23)\end{array}$ & $\begin{array}{r}-0.23 \\
(6.59)\end{array}$ \\
\hline Contiguity & $\begin{array}{c}0.49 \\
(1.51)\end{array}$ & $\begin{array}{c}0.04 \\
(0.12)\end{array}$ & $\begin{array}{c}0.53 \\
(1.80)\end{array}$ & $\begin{array}{c}0.21 \\
(1.07)\end{array}$ & $\begin{array}{c}0.30 \\
(1.05)\end{array}$ & $\begin{array}{r}-0.10 \\
(0.63)\end{array}$ \\
\hline EEC & $\begin{array}{r}-0.22 \\
(0.47)\end{array}$ & $\begin{array}{c}-0.31 \\
(0.73)\end{array}$ & $\begin{array}{c}0.18 \\
(0.40)\end{array}$ & $\begin{array}{c}0.38 \\
(1.28)\end{array}$ & $\begin{array}{c}0.63 \\
(1.54)\end{array}$ & $\begin{array}{c}0.49 \\
(2.23)\end{array}$ \\
\hline EEC-X & $\begin{array}{c}0.37 \\
(2.90)\end{array}$ & $\begin{array}{c}0.05 \\
(0.45)\end{array}$ & $\begin{array}{c}0.59 \\
(4.96)\end{array}$ & $\begin{array}{c}0.46 \\
(5.71)\end{array}$ & $\begin{array}{c}0.48 \\
(4.27)\end{array}$ & $\begin{array}{c}0.11 \\
(1.71)\end{array}$ \\
\hline GATT & $\begin{array}{c}1.84 \\
(10.55)\end{array}$ & $\begin{array}{c}1.50 \\
(9.33)\end{array}$ & $\begin{array}{c}0.19 \\
(1.19)\end{array}$ & $\begin{array}{c}-0.27 \\
(2.40)\end{array}$ & $\begin{array}{c}0.72 \\
(2.37)\end{array}$ & $\begin{array}{r}0.06 \\
(0.36)\end{array}$ \\
\hline GATT-X & $\begin{array}{c}0.61 \\
(5.42)\end{array}$ & $\begin{array}{c}0.55 \\
(5.46)\end{array}$ & $\begin{array}{c}0.00 \\
(0.01)\end{array}$ & $\begin{array}{l}-0.15 \\
(1.46)\end{array}$ & $\begin{array}{c}0.72 \\
(2.31)\end{array}$ & $\begin{array}{r}0.15 \\
(0.88)\end{array}$ \\
\hline Lagged trade & - & $\begin{array}{c}0.61 \\
(12.89)\end{array}$ & - & $\begin{array}{c}0.84 \\
(28.51)\end{array}$ & - & $\begin{array}{r}0.77 \\
(33.85)\end{array}$ \\
\hline$R^{2}$ & 0.69 & 0.75 & 0.71 & 0.87 & 0.78 & 0.92 \\
\hline Standard error & 1.02 & 0.92 & 1.02 & 0.69 & 1.00 & 0.61 \\
\hline$F$-statistic & 194.3 & 232.3 & 222.6 & 519.7 & 310.9 & 859.5 \\
\hline
\end{tabular}

Notes: T-statistics are in parentheses. Lagged trade for 1949 is trade in 1938, for 1954 trade in 1949, and for 1964 trade in 1954. EEC equals unity when both countries are EEC members, while EEC-X equals unity when one of the two countries is an EEC member. GATT equals unity when both countries are GATT members, while GATT-X equals unity when one of the two countries is a GATT member.

approach have failed to control for past trade patterns and relationships. Insofar as countries with a tendency to trade disproportionately with one another for historical reasons not otherwise captured by the gravity model also have a tendency to negotiate preferential trade arrangements to lock in those high levels of trade, there may be a tendency to spuriously attribute to the bloc variable the effects of historical factors. As already noted, we found in Eichengreen and Irwin (1995) that dummy variables for preferential arrangements often suggested statistically significant trade-creating effects even before the actual formation of those blocs. This suggests that controlling for previous trade patterns may diminish the estimated impact of trade policies on trade flows.

There is no evidence in table 2.6 that in 1949 , nearly a decade prior to the formation of the EEC, the prospective members of that regional grouping traded more extensively with one another than would be predicted by their economic characteristics (incomes, per capita incomes, distance, and contiguity) and the typical behavior of countries in the sample (as captured by the 
gravity model). ${ }^{20}$ The regression in the first column of the table suggests, curiously, a tendency for prospective EEC members to trade disproportionately with countries that were not among the founding six in 1949. This paradox evaporates when lagged trade is added to the equation, however. An interpretation is that countries like France, Belgium, and the Netherlands traded disportionately with their current and former overseas dependencies for historical reasons not readily captured by the standard arguments of the gravity model; in the standard specification, this shows up as an EEC effect-as a tendency for prospective EEC members to trade disproportionately with countries not among the founding six - where it is properly attributable to the effects of history.

GATT members appear to have traded significantly more with one another than would be predicted by the standard arguments of the gravity model as early as 1949. This is consistent with the fact the initial GATT negotiating round in 1947 succeeded in cutting the tariffs of members quite significantly. ${ }^{21}$ Strikingly, trade between GATT members and nonmembers does not appear to have been discouraged; indeed, there is evidence of a statistically significant positive effect, albeit a smaller one than that for trade between pairs of countries both of which belonged to the GATT. ${ }^{22}$ This could reflect the fact that GATT members continued to respect treaties with nonmembers that contained MFN clauses and that the Geneva tariff cuts were extended to them.

In 1954, four years prior to the formation of the EEC, there is again no evidence that the future founding members of Europe's customs union traded more heavily with one another than can be accounted for by the standard arguments of the gravity model and the typical behavior of countries in the sample. If anything, the soon-to-be founding members of the EEC tended to trade unusually heavily with countries that did not become members of the EEC in 1958. Interestingly, this effect is no longer absorbed with the addition of lagged trade, either for 1949 (as reported in the table) or even including 1938 (in results we do not report).

In 1954 GATT no longer appears to have had significant trade-creating or trade-diverting effects. This is consistent with the lack of progress toward additional multilateral trade liberalization in the 1950s and the failure of GATT to attract new members. In the regression including lagged trade (for 1949), GATT members actually appear to have traded less with one another than would be expected given their other characteristics, although this lower trade does not fully erase the positive impact apparent in 1949.

20. In addition, there is the curious result that EEC members tended to trade more heavily with nonmembers. The absence of any tendency for EEC members to trade unusually heavily with one another prior to EEC formation cannot be attributed to contiguity because, in results we do not report, the exclusion of that variable does not affect the coefficient on the EEC.

21. For a discussion of the impact of early GATT activities on trade policies in Europe and elsewhere, see Irwin (1995a, 1995b).

22. This effect fails to disappear when a control for previous trade patterns is introduced. 
The EEC's impact is evident in the regressions for 1964, when it exerts a modestly positive effect on trade with nonmembers. While GATT appears to have had positive trade-creating effects for trade both among members and between GATT signatories and the rest of the world, these effects disappear when lagged trade is accounted for. This does not mean that GATT was unimportant; insofar as earlier GATT rounds were trade creating, they stimulated lagged trade in ways that, according to the last equation in table 2.3 , continued to encourage trade in 1964. But the two equations for 1964 suggest that any positive effects arising from the Dillon Round of GATT negotiations from 1960-61 were in fact largely the effects of earlier liberalization initiatives.

Our previous paper suggested that both commercial and monetary arrangements had impacts on the pattern of trade in the 1930s. To explore this same question for the early postwar years, table 2.7 adds dummy variables to capture the effects of the leading regional monetary arrangement of the period, the European Payments Union (EPU). The EPU, created in 1950, was a generalization of previous postwar efforts to establish a framework for multilateral clearing among European countries; its participants included most of Europe (other than Spain), their overseas dependencies, and Turkey. Countries participating in the EPU agreed to adopt the Organization for Economic Cooperation and Development (OECD) Code of Liberalization committing them to remove controls and quantitative restrictions on trade with one another according to a predetermined schedule. By providing short-term credits and reestablishing a system of multilateral clearing within Europe, the EPU economized on the need for foreign exchange reserves and may have encouraged trade with the rest of the world.

Table 2.7 confirms the importance of the EPU. As in Eichengreen (1993) we find that EPU membership encouraged trade both with other EPU partners and with the rest of the world. The estimated effects of EPU membership are diminished somewhat, however, when lagged trade is included in the specification. The interpretation is that EPU members traded disproportionately with one another not just because of their preferential arrangement but also because those countries that chose to join the EPU had a disproportionate tendency to trade in the past and a special desire to rebuild their commercial relations after World War II. Once again, our results point to the importance of considering past trade as a determinant of current bilateral flows when attempting to assess the impact of preferential and regional agreements.

\section{Former Colonial Relationships}

Most colonial relationships between the European powers and developing regions persisted until the mid-twentieth century. While these relationships are known to have had an important impact on trade, it is uncertain how quickly the ties that bound a colony to its "mother country" dissolved upon independence. We provide a partial assessment of this question by analyzing trade relationships among several countries that at one time had colonial relation- 
Table 2.7

Determinants of Bilateral Trade, Including Lagged Trade and Commercial and Monetary Initiatives

\begin{tabular}{|c|c|c|c|c|c|c|}
\hline \multirow[b]{2}{*}{ Constant } & \multicolumn{2}{|c|}{1949} & \multicolumn{2}{|c|}{1954} & \multicolumn{2}{|c|}{1964} \\
\hline & $\begin{array}{c}5.07 \\
(7.57)\end{array}$ & $\begin{array}{c}3.56 \\
(5.66)\end{array}$ & $\begin{array}{c}4.68 \\
(7.26)\end{array}$ & $\begin{array}{c}1.36 \\
(2.93)\end{array}$ & $\begin{array}{c}4.15 \\
(6.05)\end{array}$ & $\begin{array}{c}2.25 \\
(5.27)\end{array}$ \\
\hline National ineomes & $\begin{array}{c}0.85 \\
(25.07)\end{array}$ & $\begin{array}{c}0.53 \\
(12.57)\end{array}$ & $\begin{array}{c}0.88 \\
(27.84)\end{array}$ & $\begin{array}{c}0.31 \\
(10.45)\end{array}$ & $\begin{array}{c}0.88 \\
(29.26)\end{array}$ & $\begin{array}{c}0.24 \\
(9.06)\end{array}$ \\
\hline $\begin{array}{l}\text { Per capita } \\
\text { national incomes }\end{array}$ & $\begin{array}{l}-0.12 \\
(2.25)\end{array}$ & $\begin{array}{r}-0.09 \\
(1.91)\end{array}$ & $\begin{array}{c}0.21 \\
(5.21)\end{array}$ & $\begin{array}{c}0.12 \\
(4.32)\end{array}$ & $\begin{array}{c}0.31 \\
(8.32)\end{array}$ & $\begin{array}{c}0.21 \\
(8.99)\end{array}$ \\
\hline Distance & $\begin{array}{l}-0.81 \\
(10.80)\end{array}$ & $\begin{array}{c}-0.57 \\
(7.86)\end{array}$ & $\begin{array}{c}-0.63 \\
(8.74)\end{array}$ & $\begin{array}{r}-0.14 \\
(2.65)\end{array}$ & $\begin{array}{l}-0.73 \\
(10.44)\end{array}$ & $\begin{array}{l}-0.27 \\
(5.89)\end{array}$ \\
\hline Contiguity & $\begin{array}{c}0.74 \\
(2.41)\end{array}$ & $\begin{array}{c}0.25 \\
(1.13)\end{array}$ & $\begin{array}{c}0.67 \\
(2.29)\end{array}$ & $\begin{array}{c}0.27 \\
(1.32)\end{array}$ & $\begin{array}{c}0.36 \\
(1.29)\end{array}$ & $\begin{array}{c}-0.11 \\
(0.62)\end{array}$ \\
\hline EEC member & $\begin{array}{l}-0.99 \\
(2.15)\end{array}$ & $\begin{array}{l}-0.87 \\
(2.08)\end{array}$ & $\begin{array}{l}-0.20 \\
(0.45)\end{array}$ & $\begin{array}{c}0.29 \\
(0.97)\end{array}$ & $\begin{array}{c}0.45 \\
(1.07)\end{array}$ & $\begin{array}{c}0.61 \\
(2.34)\end{array}$ \\
\hline $\begin{array}{l}\text { Non-EEC } \\
\text { member }\end{array}$ & $\begin{array}{c}-0.23 \\
(1.68)\end{array}$ & $\begin{array}{l}-0.38 \\
(3.02)\end{array}$ & $\begin{array}{c}0.24 \\
(1.81)\end{array}$ & $\begin{array}{c}0.36 \\
(3.96)\end{array}$ & $\begin{array}{c}0.25 \\
(2.24)\end{array}$ & $\begin{array}{c}0.14 \\
(1.77)\end{array}$ \\
\hline GATT member & $\begin{array}{c}1.91 \\
(11.53)\end{array}$ & $\begin{array}{c}1.58 \\
(10.26)\end{array}$ & $\begin{array}{c}0.11 \\
(0.69)\end{array}$ & $\begin{array}{r}-0.29 \\
(2.54)\end{array}$ & $\begin{array}{c}0.70 \\
(2.29)\end{array}$ & $\begin{array}{c}0.05 \\
(0.26)\end{array}$ \\
\hline $\begin{array}{c}\text { Non-GATT } \\
\text { member }\end{array}$ & $\begin{array}{c}0.64 \\
(6.09)\end{array}$ & $\begin{array}{c}0.57 \\
(5.80)\end{array}$ & $\begin{array}{c}-0.05 \\
(0.32)\end{array}$ & $\begin{array}{r}-0.17 \\
(1.62)\end{array}$ & $\begin{array}{c}0.69 \\
(2.21)\end{array}$ & $\begin{array}{c}0.15 \\
(0.78)\end{array}$ \\
\hline EPU member & $\begin{array}{c}1.43 \\
(6.35)\end{array}$ & $\begin{array}{c}1.14 \\
(5.53)\end{array}$ & $\begin{array}{c}0.78 \\
(3.52)\end{array}$ & $\begin{array}{c}0.18 \\
(1.18)\end{array}$ & $\begin{array}{c}0.38 \\
(1.77)\end{array}$ & $\begin{array}{r}-0.07 \\
(0.55)\end{array}$ \\
\hline $\begin{array}{l}\text { Non-EPU } \\
\text { member }\end{array}$ & $\begin{array}{c}0.97 \\
(8.38)\end{array}$ & $\begin{array}{c}0.70 \\
(6.39)\end{array}$ & $\begin{array}{c}0.66 \\
(5.76)\end{array}$ & $\begin{array}{c}0.18 \\
(2.32)\end{array}$ & $\begin{array}{c}0.39 \\
(3.47)\end{array}$ & $\begin{array}{r}-0.03 \\
(0.47)\end{array}$ \\
\hline Lagged trade & - & $\begin{array}{c}0.46 \\
(11.54)\end{array}$ & - & $\begin{array}{r}0.81 \\
(27.52)\end{array}$ & - & $\begin{array}{r}0.87 \\
(33.47)\end{array}$ \\
\hline$R^{2}$ & 0.72 & 0.77 & 0.73 & 0.87 & 0.78 & 0.92 \\
\hline Standard error & 0.97 & 0.89 & 1.00 & 0.69 & 1.00 & 0.62 \\
\hline$F$-statistic & 181.1 & 208.2 & 189.8 & 430.3 & 253.6 & 705.3 \\
\hline
\end{tabular}

Notes: See table 2.4 notes. Lagged trade for 1949 is trade in 1938, for 1954 trade in 1949, and for 1964 trade in 1954.

ships. We first consider trade after World War II among the countries that had composed the British Empire and were within the British Commonwealth. Our sample of British colonies is more broadly defined than the British Commonwealth, which retained within-group trade preferences even after the war, and includes such areas as Palestine (Israel), Ireland (which quit the Commonwealth in 1948), and British Malay (Malaysia, which joined the Commonwealth in 1957), as well as Commonwealth members Canada, Australia, India, New Zealand, Pakistan, South Africa, and the United Kingdom.

Table 2.8 reports the coefficients on the variable denoting pairs of bloc members and that denoting trade between members and nonmembers. ${ }^{23}$ All the summary statistics and other coefficients are comparable to those found on the

23. The regressions exclude other blocs, such as GATT and the EEC, but our results are robust to their inclusion. 


\begin{tabular}{|c|c|c|c|}
\hline \multirow{12}{*}{$\begin{array}{l}\text { British } \\
\text { Commonwealth }\end{array}$} & 1949 & 1.83 & 1.13 \\
\hline & & $(5.77)$ & $(3.97)$ \\
\hline & & 0.13 & 0.15 \\
\hline & & $(1.17)$ & $(1.52)$ \\
\hline & 1954 & 0.89 & -0.25 \\
\hline & & $(3.22)$ & $(1.31)$ \\
\hline & & 0.34 & -0.33 \\
\hline & & $(3.27)$ & $(5.62)$ \\
\hline & 1964 & 0.65 & -0.01 \\
\hline & & $(2.86)$ & $(0.08)$ \\
\hline & & -0.35 & -0.12 \\
\hline & & $(3.59)$ & $(2.34)$ \\
\hline \multirow{12}{*}{$\begin{array}{c}\text { United States- } \\
\text { Philippines }\end{array}$} & 1949 & 2.44 & 1.77 \\
\hline & & $(2.16)$ & $(1.81)$ \\
\hline & & 0.12 & 0.36 \\
\hline & & $(0.83)$ & $(2.70)$ \\
\hline & 1954 & 1.32 & -0.21 \\
\hline & & $(1.25)$ & $(0.29)$ \\
\hline & & -0.31 & -0.30 \\
\hline & & $(2.24)$ & $(3.21)$ \\
\hline & 1964 & 1.73 & 0.08 \\
\hline & & (1.69) & $(0.12)$ \\
\hline & & 0.11 & 0.08 \\
\hline & & $(0.89)$ & $(0.12)$ \\
\hline \multirow{12}{*}{$\begin{array}{l}\text { Netherlands- } \\
\text { Indonesia }\end{array}$} & 1949 & 3.30 & 1.85 \\
\hline & & (2.99) & $(1.89)$ \\
\hline & & -0.33 & -0.38 \\
\hline & & $(2.36)$ & (3.16) \\
\hline & 1954 & 3.66 & 0.63 \\
\hline & & (3.53) & $(0.89)$ \\
\hline & & 0.35 & 0.24 \\
\hline & & $(2.73)$ & $(2.71)$ \\
\hline & 1964 & 2.51 & -0.43 \\
\hline & & $(2.47)$ & $(0.69)$ \\
\hline & & 0.24 & -0.10 \\
\hline & & $(1.92)$ & $(1.31)$ \\
\hline
\end{tabular}

Basic

Specification

British colonies

1964

1954

1949

0.86

(3.82)

0.00

$(0.01)$

0.19

$(0.95)$

$-0.34$

(3.39)

0.00

$(0.00)$

$-0.41$

(4.50)

1.83

(1.17)

(3.22)

0.34

0.65

(3.59)

(2.16)

0.12

1.32

(1.25)

(2.24)

1.73

(1.69)

0.11

(2.99)

$-0.33$

(3.53)

0.35

2.51

0.24
Including

Lagged Trade

0.13

(0.81)

$-0.11$

(1.13)

$-0.33$

(2.49)

$-0.34$

(5.16)

$-0.14$

(1.26)

$-0.13$

(2.19)

1.13

0.15

(1.52)

$-0.25$

$-0.33$

(0.08)

$-0.12$

(2.34)

(1.81)

0.36

(2.70)

$-0.21$

(0.29)

$-0.30$

(3.21)

0.08

$(0.12)$

$(0.12)$

1.85

$-0.38$

(3.16)

(0.89)

(2.71)

$-0.43$

(0.69)

(1.31)

Note: See table 2.4 notes. 
other tables. The result for 1949 obtained from estimating the standard gravitymodel specification suggests that countries that had once been members of the British Empire continued to trade unusually heavily with one another immediately after World War II. As the reader will by now be well aware, this effect could reflect either Commonwealth preferences (which were maintained until the United Kingdom entered the EEC in the early 1970s) or the persistent influence of past trade on current trade. The second column in table 2.8 points to the latter interpretation: former British colonies traded disproportionately more with one another in 1949 not because of the trade-creating effects of Commonwealth preferences but because of the effects of history.

For 1954 and 1964 the standard specification suggests no trade-creating effects among the former colonies but some trade diversion. Adding lagged trade suggests, strikingly, that members of the British Commonwealth and Britain's former colonies tended to trade less than predicted by the standard arguments of the gravity model, both with one another and with the rest of the world, once the effects of history are taken into account. This is consistent with historical accounts (viz. Schenk 1994) suggesting that Britain failed to reorient its trade toward continental Europe and other parts of the world in the 1950s. This is also suggestive of an unraveling of the trade and transportation networks that had once bound these disparate regions together. Countries of the empire appear to trade less with others than would have been anticipated, even when accounting for past trade patterns. A possible interpretation is that, as colonial networks dissolved, the former colonies lost access to the British "hub" (wherein Britain acted as an entrepôt and reexported colonial goods) that allowed the colonies to maintain trading ties with countries they might normally not trade with.

The results for the British Commonwealth suggest that these countries traded unusually heavily with one another in 1949, even when controlling for the pattern of trade in 1938. This effect disappears in 1954 and 1964 once lagged trade is included, although the negative effect on trade with nonmembers is still apparent.

We also examined trade ties between the United States and the Philippines and between the Netherlands and Indonesia. The results suggest that largerthan-expected trade flows between these countries are properly attributed to the effects of history, except in 1949.

\subsection{Conclusions and Implications}

Our goal in this paper has been to make a simple point. We have argued that both theory and evidence suggest that history plays a role in shaping the direction of international trade. The standard gravity-model formulation, which neglects the role of historical factors, suffers from omitted-variables bias. Because there are reasons to anticipate a positive correlation between the predominant direction of trade flows in the past and membership in preferential 
arrangements in the present, there may be a tendency to spuriously attribute to preferential arrangements the effects of historical factors and to exaggerate the influence of the former.

We have illustrated these points by analyzing the evolution of trade between 1949 and 1964. We found that lagged trade exercises an important effect even after controlling for the arguments of the standard gravity model. While it is always appropriate to interpret the coefficients on lagged dependent variables with caution, our findings are robust to the use of instrumented values in place of actual values of lagged trade to better distinguish persistent effects of trade from persistent random effects (where the gravity model conveniently furnishes the logical instruments). Among our substantive findings are that the omission of historical factors overstates the trade of the countries of continental Europe with its former colonies after the late 1940s, that it exaggerates the trade-creating effects of the EPU, and that it overstates the importance of the Dillon Round of the early 1960s.

The implication is that we will never run another gravity equation that excludes lagged trade flows. If our paper is successful (and widely read), neither will other investigators.

\section{References}

Anderson, James E. 1979. A Theoretical Foundation for the Gravity Equation. American Economic Review 69:106-16.

Baldwin, Richard E. 1988. Hysteresis in Import Prices: The Beachhead Effect. American Economic Review 74:773-85.

Baldwin, Richard E., and Paul Krugman. 1989. Persistent Trade Effects of Exchange Rate Shocks. Quarterly Journal of Economics 104:635-54.

Bayoumi, Tamim, and Barry Eichengreen. 1995. Is Regionalism Simply a Diversion? Evidence from the Evolution of the EC and EFTA. International Monetary Fund and University of California, Berkeley. Manuscript.

Bean, Charles R. 1988. Sterling Misalignment and British Trade Performance. In Richard C. Marston, ed., Misalignment of Exchange Rates: Effects on Trade and Industry. Chicago: University of Chicago Press.

Bergstrand, J. H. 1985. The Gravity Equation in International Trade: Some Microeconomic Foundations and Empirical Evidence. Review of Economics and Statistics $67: 474-81$.

Deardorff, Alan. 1984. Testing Trade Theories and Predicting Trade Flows. In Ronald Jones and Peter Kenen, eds., Handbook of International Economics, 1:467-517. Amsterdam: Elsevier.

Dewhurst, J. Frederic, John O. Coppock, P. Lamartine Yales, and associates. 1961. Europe's Needs and Resources. New York: Twentieth Century Fund.

Dixit, Avinash. 1989. Hysteresis, Import Penetration, and Exchange Rate Pass Through. Quarterly Journal of Economics 104:205-28.

Eichengreen, Barry. 1993. Reconstructing Europe's Trade and Payments. Manchester: Manchester University Press; Ann Arbor: University of Michigan Press. 
Eichengreen, Barry, and Douglas A. Irwin. 1995. Trade Blocs, Currency Blocs, and the Reorientation of Trade in the 1930s. Journal of International Economics 38:1-24.

Frankel, Jeffrey. 1995. Regional Trade Blocs. Washington, DC: Institute for International Economics.

Frankel, Jeffrey, Ernesto Stein, and Shang-Jin Wei. 1993. Continental Trading Blocs: Are They Natural or Supernatural? NBER Working Paper no. 4588. Cambridge, MA: National Bureau of Economic Research, June.

Frankel, Jeffrey, and Shang-Jin Wei. 1993. Trade Blocs and Currency Blocs. In Centre for Economic Policy Research, The Monetary Future of Europe. London: Centre for Economic Policy Research.

Greene, W. H. 1993. Econometric Analysis. 2d ed. New York: Macmillan.

Griliches, Zvi. 1961. A Note on the Serial Correlation Bias in Estimates of Distributed Lags. Econometrica 29:65-73.

Hamilton, Carl, and L. Alan Winters. 1992. Opening Up International Trade in Eastern Europe. Economic Policy 14:77-117.

Hilgert, Folke. 1942. The Network of World Trade. Geneva: League of Nations.

Irwin, Douglas A. 1995a. The GATT in Historical Perspective. American Economic Review Papers and Proceedings 85:323-28.

. 1995b. The GATT's Contribution to Economic Recovery in Post-War Europe. In Barry Eichengreen, ed., Europe's Postwar Growth, Revisited. New York: Cambridge University Press.

Kaufman, Burton I. 1974. Efficiency and Expansion: Foreign Trade Organization in the Wilson Administration, 1913-1921. Westport, CT: Greenwood Press.

Liviatan, N. 1963. Consistent Estimation of Distributed Lags. International Economic Review 4:44-52.

Mitchell, Brian R. 1993. International Historical Statistics: The Americas, 1750-1988. 2d ed. New York: Stockton Press.

Roberts, Mark J., and James R. Tybout. 1995. The Decision to Export: An Empirical Model of Entry with Sunk Costs. Georgetown University. Mimeo.

Saul, S. B. 1960. Studies in British Overseas Trade, 1870-1914. Liverpool: Liverpool University Press.

Schenk, Susan. 1994. Britain and the Sterling Area: From Devaluation to Convertibility. London: Routledge.

\section{Comment Robert Z. Lawrence}

In this paper, Eichengreen and Irwin argue that traditional gravity models are incompletely specified because they fail to take account of the likelihood that trade patterns will be influenced by history, that is, previous trade. In principle, this could seriously bias the estimates obtained on the independent variables in traditional models if these are correlated with variables that are omitted. Eichengreen and Irwin argue that this is in fact the case and present evidence that shows how the coefficients on traditional variables are dramatically altered when a lagged dependent variable is introduced into the estimation. On the

Robert Z. Lawrence is the Albert L. Williams Professor of International Trade and Investment at the Kennedy School of Government, Harvard University, and a research associate of the National Bureau of Economic Research. 
basis of these results, they promise never again to run gravity models that exclude historical trade flows, and advise other modelers to do the same.

I think the paper does succeed in raising some important questions about the use of these models, but I'm not sure where it leaves us. I take away the message that it is important to interpret these models with great care, although I am not convinced that simply introducing a lagged dependent variable will suffice. In my view, there is no substitute for including both current and lagged exogenous determinants of trade flows explicitly in the equation.

An important question is what do the estimated parameters in the model actually mean when estimated together with the lagged dependent variable? Should these coefficients be viewed simply as historical descriptions of the relationship between the variables or can they be thought of as time-related structural parameters? The authors seem to be on both sides of this issue. In the introduction to the paper, they note that "the influence of past trade over current trade may vary with circumstances" - in other words this influence is not stable or structural-and this observation is supported by the results reported in table 2.4 , which indicate that past trade has variable effects. However, in their discussion of table 2.4 the authors imply that these coefficients are structurally stable when they infer effects such as the implied long-run income elasticity. I doubt this practice gives us very good answers. It is noteworthy that the coefficient on the contemporaneous income variable is virtually unchanged between 1954 and 1964 at 0.25 and 0.27 respectively; the implied long-run elasticity increases dramatically from 2.6 to 4.5 . These results suggest that income operates on trade with extremely long lags - and while most macrotrade equations do suggest lagged effects, they do not indicate these are felt for more than a year or two.

The structural interpretation using a lagged dependent variable constrains the timing of adjustment to all independent variables to be the same. But I find this implausible. We know from macrotrade equations, for example, that price effects generally operate more slowly than income effects. In this case, the full effects of concluding a free trade area, for example, are likely to take much longer than an increase in income. It would be interesting therefore if the lagged income variables, rather than (or in addition to) the lagged dependent variable, were included in the regression.

Another hint of the problems in providing a structural interpretation comes in table 2.6. Suppose you want to use table 2.6 to know what being a member of the European Community (EC) does to trade. Is the answer 0.49 , the dummy on the EC in 1964, or should the coefficient be taken in conjunction with the lagged dependent variable of 0.77 to obtain estimates that are six times as large? In this case, the lagged variable is estimated using trade from 1954 when countries were not even members of the EC.

As is the case in time-series analysis, the appearance of lagged dependent variables with large coefficients can be rationalized as lagged adjustment, but it may also indicate serious misspecification. The best approach, therefore, is 
not simply to drop the lagged dependent variable into the equation but to try explicitly to capture the truly exogenous variables that affected lagged trade.

The issue of exogeneity may also be an important problem when dummy variables are used to estimate the effects of free trade areas. Free trade areas may well be an endogenous variable - that is, a response to, rather than a source of, large trade flows. Frankel and Wei and others have used gravity models to determine which groups of countries form "natural" trading blocs. Presumably, such groups are more likely to form free trade areas, since the benefits outweigh the costs. Similarly, it is argued that in Asia, in particular, formal agreements are following the market, whereas in Europe it seems more likely that these arrangements have tended to lead. If we find a large coefficient on a particular free trade area, is that an indication the agreement has strong effects or simply that the countries that have formed the agreement have chosen well?

\section{Comment Paul Wonnacott}

As we have come to expect, Eichengreen and Irwin have presented a careful and interesting paper on a current topic, adding a historical perspective. Their main point, that past trade patterns continue to influence current trade flows, is, as they note, "intuitively plausible." They present empirical evidence supporting this plausible viewpoint. In the introductory section, they also present historical examples, of which I find South African exports to the London gold market to be one of the more compelling. Indeed, South Africa is perhaps one of the more interesting examples one can think of: not only can the gold market be cited, but South African exports of diamonds to the Netherlands likewise show the importance of history and established commercial relationships in determining current trade patterns.

In any paper with such a broad scope, there are always points on which additional information could be brought in, or additional hypotheses tested. I have no quarrel with the choices of Eichengreen and Irwin from the options open to them; their choices seem reasonable and well motivated. And, to keep the paper manageable, they were forced to follow Yogi Berra's advice: when you come to a fork in the road, take it. I would, nevertheless, like to suggest some alternative ideas that might be worth considering. I will pass over the issues raised by the general tendency for lagged variables to be relatively powerful explanatory variables, and concentrate on the more specific issues raised by the paper.

First, and perhaps most important, is what one makes of the persistence of historical trade patterns. The emphasis of their paper is on historical accidents,

Paul Wonnacott is the Alan R. Holmes Professor at Middlebury College. 
such as empires or wars, that lead to new trade patterns. Once costs are sunk in developing new markets, the resulting trade pattern generally persists, in large part because of economies of scale.

Without questioning the validity of this conclusion, I would like to suggest an additional explanation for the persistence of historical patterns of trade. Trade is driven not just by the variables in the gravity model and by historical accident, but also by the traditional idea of comparative advantage. While comparative advantage can change, it generally does so only slowly. Thus, for example, temperate countries with fertile prairie lands are quite likely to export wheat to heavily populated countries with poor soil, and this trading pattern is likely to persist. Similarly, one would explain Japanese imports from the Persian Gulf by the large supplies of oil there, and the thirst of Japanese industry for that oil. Likewise, bauxite is shipped from countries that have bauxite mines to those that have plentiful supplies of electric power, most notably cheap hydropower, and both the bauxite supplies and the hydropower are likely to last for an extended period of time.

What difference, it might be asked, does this make? Why should we care whether persistent trade patterns are the result of historical accidents - such as war or empire - or whether they are the result of things that might be classified under the concept of comparative advantage? It matters quite a bit in terms of the main topic of this conference-namely, regional arrangements. If, prior to the establishment of a free trade association, countries are close trading partners because of fundamental economic forces - those of classical comparative advantage and geographical proximity - then I would argue that the case for a free trade agreement is strengthened. The countries are natural trading partners, and discrimination against outsiders that any such agreement entails is likely to have relatively weak trade-diverting effects.

In contrast, if the high level of trade is explained on the basis of historical accident, then discrimination against outsiders is more questionable. Sunk costs are of course real costs, and cutting across traditional lines of commerce-such as between the South African and London gold markets or the South African and Dutch diamond markets - can inflict real losses. But fortifying traditional ties by discriminating against new outside competitors strikes me as less desirable than fortifying the natural advantages that come from geographical proximity or from comparative advantage in the traditional sense.

Second, Eichengreen and Irwin struggle with a puzzle, that dummy variables for regional arrangements often show up even before the regional agreement comes into effect, sometimes long before. Perhaps there is a relatively straightforward explanation for this advanced effect. Comprehensive regional arrangements are often preceded with more limited agreements. For example, the Treaty of Rome was preceded by the European Coal and Steel Community (ECSC). In addition, the European Union (EU) was preceded by the dollar shortage and the European Payments Union (EPU), which gave preference to intra-European trade even before the Treaty of Rome. There were 
also powerful noneconomic objectives at work, both in ECSC and the Treaty of Rome. An objective of ECSC was to integrate so thoroughly the French and German coal and steel industries that a fourth Franco-Prussian war would become impossible. For the Treaty of Rome, a significant political objective was to develop a strong integrated unit that would be able to withstand challenges from the east. These political objectives could also have led to greater intra-European trade even before the Treaty of Rome. Political objectives were of course also the reason for U.S. support for the European Community (EC), even though we would be discriminated against. For details on the pre-Rome increase in trade within Western Europe, I defer to Eichengreen, as he has already done extensive research with Bayoumi (1995).

In North America, there were likewise preliminary steps that increased trade prior to the signing of the Canada-U.S. Free Trade Agreement and North American Free Trade Agreement (NAFTA). The Canada-U.S. FTA was preceded by more than two decades by the Auto Pact of 1965, which led to a very rapid increase in the trade of manufactures between the two countries.

On the Mexican side, the maquiladora industries had special access to the U.S. market prior to beginning of NAFTA negotiations.

On the broader issue of "anticipation" of a regional agreement, the three cases I have cited-Europe, United States, Canada, and NAFTA — seem quite different. U.S.-Canadian free trade was a topic off and on for well over a hundred years, dating back to the Reciprocity Treaty that preceded the Canadian Confederation. A free trade agreement was negotiated in 1911 , but rejected at the polls. A preliminary secret agreement was reached shortly after the Second World War, but Prime Minister King got cold feet and withdrew. From the 1960s on, there was a major shift in Canadian business opinion, away from import protection, and toward assured and open access to the U.S. market as a goal.

The European case seems to me to fall into the middle-laying aside attempts by Napoleon and Hitler to unify the continent with the sword. There was a period of about ten years of growing attention before the Treaty of Rome was signed. The Mexican period of anticipation was much shorter; the 1990 approach was the result of a very rapid change in Mexican politics.

In short, all three comprehensive regional agreements were preceded by limited special arrangements. But the degree of anticipation of the comprehensive agreements varied sharply among the three cases.

It is possible that mutual causation was at work, helping to explain the apparent advanced effect of regional arrangements. Nations that are increasingly trading with one another may gradually begin to consider a free trade association or customs union. This fits into my first point: insofar as countries are naturally growing together, the economic case for a regional arrangement is strengthened. The problem here, however, is that the case is muddied by the special arrangements made along the way. For example, the preferential Auto Pact was a significant contributor to the growth of U.S.-Canadian trade after 
1965, and this trade should be discounted in any attempt to quantify whether the United States and Canada were becoming natural trading partners.

Third, let me touch on a potpourri of small points in the Eichengreen-Irwin paper.

It is puzzling that the Asia-Pacific Economic Cooperation (APEC) shows up as having substantial trade-creating effects, since it provides no preferences, although it does constructive work in such things as customs clearance procedures. I find it hard to believe that people have much confidence that an APEC free trade association will actually come into effect within the next decade, in spite of official pronouncements. Perhaps there are alternative explanations for the increase in trade. The APEC area is the center of economic dynamism; rapidly growing countries may have a tendency to trade intensively with other rapidly growing countries-even more than one would expect simply on the basis of national product or per capita national product. Is there a case for putting the rate of growth of per capita income as an argument in gravity models? Do the high and rising income elasticities of trade in table 2.4 of the Eichengreen-Irwin paper suggest that the answer to this question might be yes?

In dealing with the possible alternative explanations for the postwar persistence of trade within the Commonwealth and between continental Europe and its colonies, perhaps it would be worth considering monetary arrangements. The discriminations involved in, say, the sterling area may have been as important as traditionally defined commercial policies.

Finally, with the authors, I am puzzled by lack of trend in the distance coefficient (tables 2.2 and 2.3: -0.78 in 1928 to -0.81 in 1964). One would have thought that the decline in transportation costs over time would have caused a trend. But two interesting changes did occur in the coefficient-a substantial decline in the absolute size of the coefficient during the 1930s, and an even bigger increase in the 1940s. Was the fall of the absolute size of the distance coefficient in the 1930s the combined result of the general strangling of trade, together with the rise of importance of preferential trade in the far-flung British Empire? Was the increase in absolute size of the coefficient in the 1940s the result of the postwar financial mess, and the tendency to make bilateral and regional financial arrangements in the face of the "dollar shortage"?

These are some of the questions that arose as I read the Eichengreen-Irwin paper. I congratulate them on an interesting and thought-provoking paper.

\section{Reference}

Bayoumi, Tamim, and Barry Eichengreen. 1995. Is Regionalism Simply a Diversion? Evidence from the Evolution of the EC and EFTA. International Monetary Fund and the University of California, Berkeley. Manuscript. 